\title{
Krukenberg's tumor in the young population
}

\author{
PRABHA GUPTA, MD \\ MACKIE A. SNEBOLD, DO \\ SCOTT O'DONNELLY, DO
}

\begin{abstract}
Krukenberg's tumor secondary to gastric adenocarcinoma was identified in a 20 -year-old woman. The patient died ten weeks after surgery, which included total hysterectomy, bilateral salpingo-oophorectomy, tumor debulking, and subtotal gastrectomy. Her unexpected advanced disease and fulminant course led the authors to review the literature for other reports of Krukenberg's tumor in the young person. However, the age category was not studied specifically in most series, and only a few cases involving patients of very young age were detailed. The present case appears to be only the fifth involving a patient aged 20 years.
\end{abstract}

In 1896, Frederick Krukenberg ${ }^{1}$ described bilateral ovarian enlargements caused by secondary adenocarcinoma of the ovaries. Histologically, Krukenberg's tumor is composed of malignant, mucinproducing signet-ring cells in an abundant fibrous stroma. ${ }^{2}$ Primary sites usually are the stomach or colon; less commonly, the breast, gallbladder, small bowel, pancreas, uterus, or urinary bladder harbors the primary cancer..$^{2-4}$

The average age of patients with Krukenberg's tumor is 40 to $\mathbf{4 5}$ years, and the tumor rarely is seen in patients younger than 35 years. ${ }^{5}$ The patient in our case was 20 years old at diagnosis, and, thus, she was one of the youngest persons reported to have Krukenberg's tumor.

\section{Report of case}

A 20-year-old, nulliparous woman was admitted complaining of abdominal pain and increasing abdominal girth of three months' duration. There was no significant medical or family history.
The patient was 62 in tall and weighed $183 \mathrm{lb}$. Her blood pressure was $140 / 90 \mathrm{~mm} \mathrm{Hg}$, and she had a lowgrade fever (temperature of $99.6^{\circ} \mathrm{F}$ ). Facial hair growth was slightly increased. The abdomen was soft, distended, and tender. No masses were appreciated, and a fluid wave was possibly present.

The patient initially refused pelvic and rectal examinations because of her discomfort. Pregnancy and $\mathrm{Pa}$ panicolaou's tests had negative findings. The erythrocyte sedimentation rate was elevated to $47 \mathrm{~mm} / \mathrm{h}$.

An upper gastrointestinal roentgenographic series revealed irregularity along the greater curvature of the stomach. Pelvic sonography and abdominal computed tomography revealed massive ascites, and bilateral, large, complex ovarian masses measuring between $7 \mathrm{~cm}$ and $9 \mathrm{~cm}$ as well as bilateral hydrothorax; these findings were consistent with Meig's syndrome. Barium enema study of the colon showed no abnormalities.

Laparotomy revealed the following abnormalities: (1) Bilateral, symmetric ovarian enlargement, with extensive involvement of peritoneum, omentum, and the se-

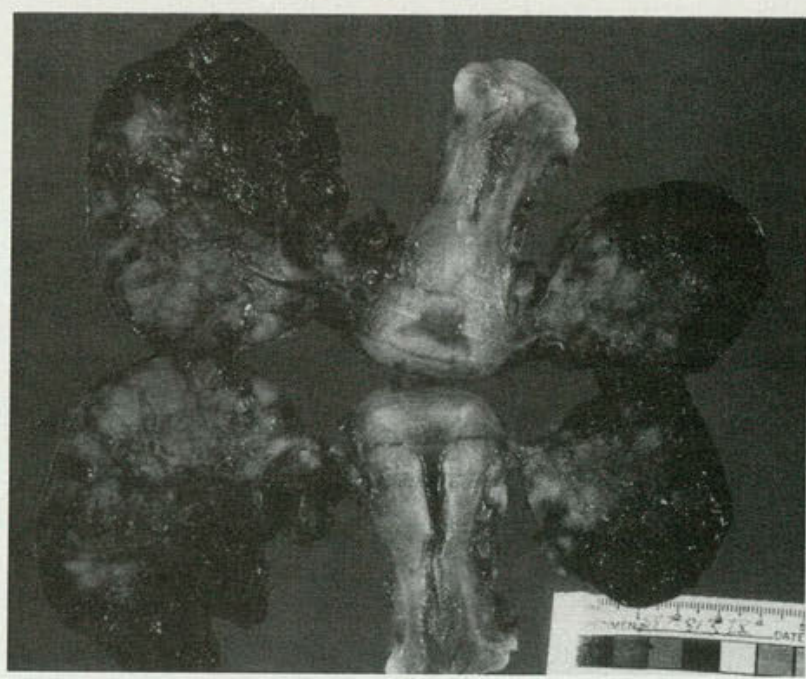

Fig 1. Excised Krukenberg's tumor, with bilateral ovarian enlargement. 
rosal surface of abdominal organs; (2) a palpable gastric mass involving the greater curvature of the stomach; and (3) massive ascites (volume, $4 \mathrm{~L}$ ). Total hysterectomy, bilateral salpingo-oophorectomy, debulking of the tumor, and subtotal gastrectomy were performed.

The excised ovarian tumor is shown in Fig 1. The histopathologic impression was that of gastric carcinoma, with bilateral ovarian metastasis and widespread involvement of omentum, peritoneum, and regional abdominal lymph nodes. The gastric neoplasm was consistent with primary adenocarcinoma (linitis plastica type), and the ovaries contained secondary adenocarcinoma with mucinpositive signet-ring cells (Figs 2,3). Ascitic and pleural fluids were positive for adenocarcinoma.

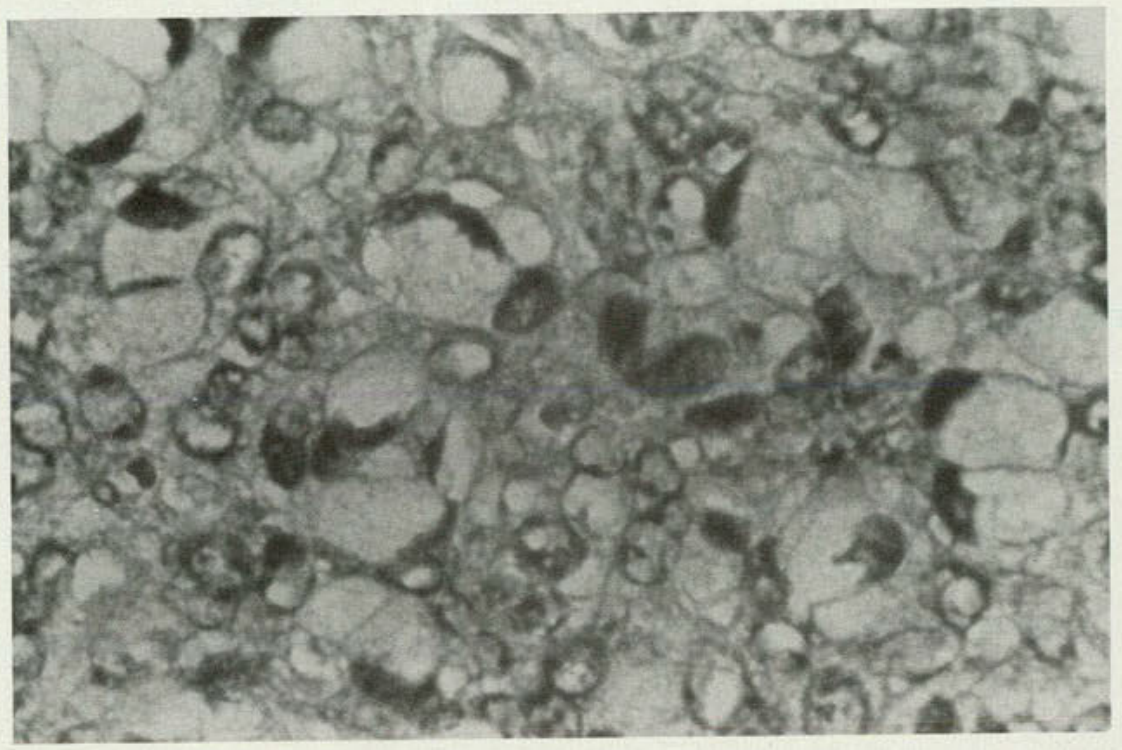

Fig 2. Signet-ring cells in ovary (hematoxylin and eosin stain; original magnification $\times 40$ ).

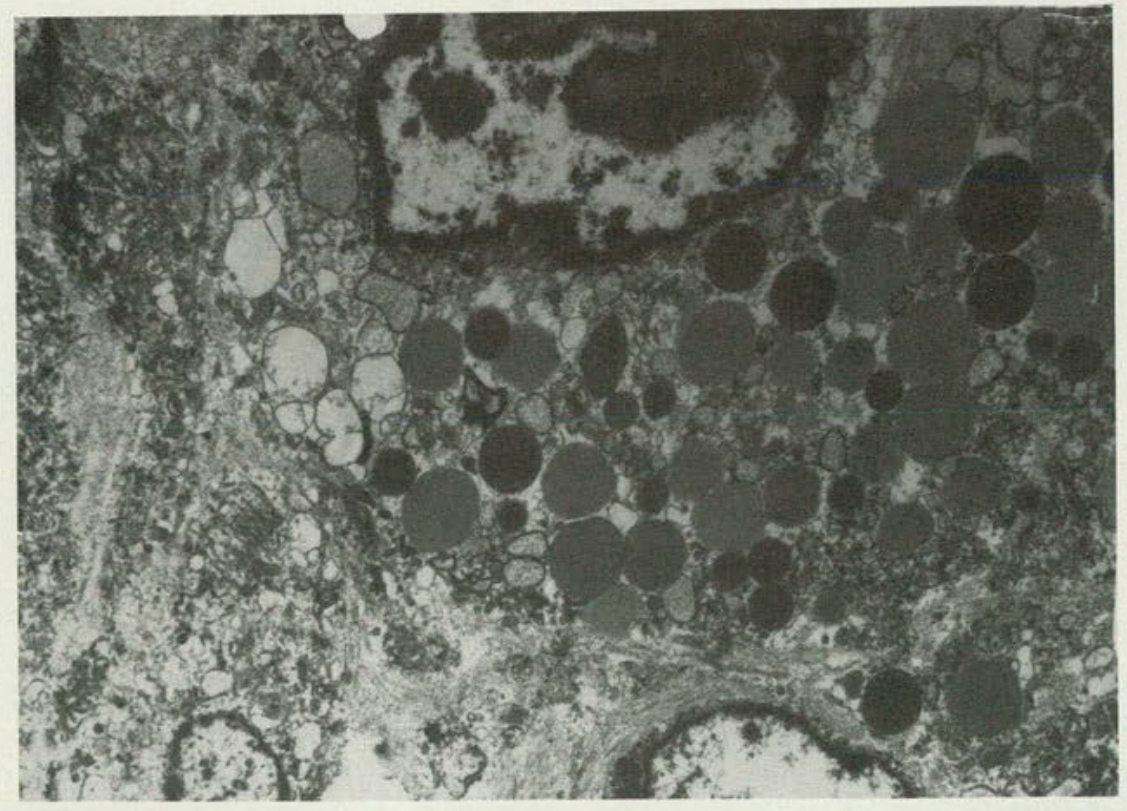

Fig 3. Signet-ring cells in ovary and large, pale mucous granules and dark, dense mucous granules (electron microscopy, original magnification $\times 30,000$ ).
Postoperatively, the patient's course was complicated by persistent, malignant pleural effusions and hypoproteinemia. Chemotherapy was withheld because of her poor medical status. She died approximately ten weeks after surgery.

\section{Discussion}

A computer search of the English medical literature back to 1938 revealed no studies of Krukenberg's tumor that dealt specifically with the age of patients. Most reports mentioned only broad age groups. Except in isolated reports and in Hale's ${ }^{5}$ series, it was difficult finding the exact age of each patient. Only three patients as young or younger than our patient have been reported to have Krukenberg's tumor, with a fourth patient described only as "a young girl." $3,6-8$

Gastric carcinoma in the young population was reviewed in two studies. In McNeer's ${ }^{9}$ series of 501 patients with gastric carcinoma who were younger than 31 years, 50 had Krukenberg's tumor. Exact ages, however, were not reported clearly in this study. Tamura and Curtiss $^{10}$ identified 11 cases of ovarian metastasis from gastric primary carcinoma in patients younger than 36 years. Again, individual ages were not given. Table 1 reviews nine series ${ }^{3,5,7,8,11-15}$ of Krukenberg'stumor published in the past 50 years.

One of the more widely discussed series was published by Woodruff and Novak ${ }^{7}$ in 1960. In reviewing 1,700 cases recorded in the Ovarian Tumor Registry during a 17-year period, they found 48 cases of Krukenberg's tumor. The age range in the series was 16 to 61 years; however, individual ages were not provided. The authors state that the youngest patient was 13 years old, but the reference case is unknown. In this study, $80 \%$ of the patients had bilateral tumors and $50 \%$ of the patients had gross evidence of malignancy, with metastatic disease in the abdominal cavity.

The single largest study of Krukenberg's tumor (81 cases) 


\begin{tabular}{|c|c|c|c|c|c|c|}
\hline \multirow[b]{2}{*}{ Study date } & \multirow[b]{2}{*}{ Author(s) } & \multicolumn{3}{|c|}{ Age } & \multirow[b]{2}{*}{ Primary site (No.) } & \multirow[b]{2}{*}{ Survival data } \\
\hline & & $\begin{array}{l}\text { No. of } \\
\text { cases }\end{array}$ & $\begin{array}{c}\text { Range } \\
(\mathrm{yr})\end{array}$ & $\begin{array}{c}\text { Mean } \\
(\mathrm{yr})\end{array}$ & & \\
\hline 1938 & $\begin{array}{l}\text { Novak and } \\
\text { Gray }^{11}\end{array}$ & 21 & $22-60$ & 42 & $\begin{array}{l}\text { Stomach }(6) \\
\text { Color }(5) \\
\text { Unknown }(10)\end{array}$ & $\begin{array}{l}\text { Follow-up in } 17 \text { of } 21 \text { cases. Death of } \\
13 \text { patients within six weeks to } 14 \\
\text { months. Death imminent for three } \\
\text { patients when last seen. Only one } \\
\text { patient with presumed primary } \\
\text { Krukenberg's tumor was alive and } \\
\text { well after four years. }\end{array}$ \\
\hline 1951 & $\mathrm{Karsh}^{4}$ & 4 & $28-47$ & 39 & $\begin{array}{l}\text { Stomach (3) } \\
\text { Gallbladder (1) }\end{array}$ & Not discussed. \\
\hline 1956 & Soloway et $\mathrm{al}^{13}$ & 16 & $30-61$ & 44 & $\begin{array}{l}\text { Stomach }(9) \\
\text { Breast (4) } \\
\text { Sigmoid colon (1) } \\
\text { Unestablished (2) }\end{array}$ & $\begin{array}{l}\text { Average survival time was } 6.6 \\
\text { months. Longest survival was } \\
28 \text { months. One patient was alive } \\
\text { after } 24 \text { months. }\end{array}$ \\
\hline 1960 & $\begin{array}{l}\text { Woodruff and } \\
\text { Novak }^{7}\end{array}$ & $48^{*}$ & $16-61$ & 40 & $\begin{array}{l}\text { Stomach (19) } \\
\text { Breast (4) } \\
\text { Gallbladder (1) } \\
\text { Colon (1) } \\
\text { Undetermined (13) } \\
\text { No other primary } \\
\quad \text { site identified (10) }\end{array}$ & $\begin{array}{l}\text { Five patients lived four or more } \\
\text { years; four of the five had a known } \\
\text { primary site other than the ovary. }\end{array}$ \\
\hline 1968 & Hale $^{5}$ & 81 & $21-81$ & 45 & $\begin{array}{l}\text { Stomach }(76) \\
\text { Breast }(2) \\
\text { Sigmoid colon (2) } \\
\text { Cecum (1) }\end{array}$ & $\begin{array}{l}\text { One patient alive at } 45 \text { months. } \\
\text { Longest other survival was } 20 \\
\text { months. Death occurred at an } \\
\text { average of } 9.8 \text { months from onset } \\
\text { of symptoms and at an average of } \\
7.1 \text { months after diagnosis. }\end{array}$ \\
\hline 1968 & $\mathrm{Joshi}^{8}$ & $18^{\dagger}$ & $16-61$ & 38 & $\begin{array}{l}\text { Classified as primary } \\
\text { Krukenberg's tumor (no } \\
\text { other known primary } \\
\text { site). }\end{array}$ & $\begin{array}{l}\text { Survival was analyzed in nine cases. } \\
\text { Four patients lived longer than } \\
\text { five years (several days to } 14 \\
\text { months longer). }\end{array}$ \\
\hline 1981 & Bullon et at ${ }^{14}$ & 13 & $29-84$ & $47 \ddagger$ & $\begin{array}{l}\text { Tubular Krukenberg's } \\
\text { tumor } \\
\text { Stomach (4) } \\
\text { Sigmoid colon (1) } \\
\text { Appendix (1) } \\
\text { Undetermined (7) }\end{array}$ & $\begin{array}{l}\text { Ten of } 13 \text { patients died with dissemi- } \\
\text { nated tumor from two to } 21 \\
\text { months postoperatively (variety of } \\
\text { surgical procedures). Two patients } \\
\text { were alive without evidence of dis- } \\
\text { ease seven to nine months } \\
\text { postoperatively. }\end{array}$ \\
\hline 1982 & Holtz and Hart ${ }^{3}$ & 27 & $20-70$ & $46 \S$ & $\begin{array}{l}\text { Stomach (16) } \\
\text { Colon (4) } \\
\text { Unknown (7) }\end{array}$ & Not discussed. \\
\hline 1986 & Wong et al 15 & 15 & $30-72$ & 44 & $\begin{array}{l}\text { Stomach (4) } \\
\text { Breast (1) } \\
\text { Ampulla of Vater (1) } \\
\text { Colon (1) } \\
\text { Unknown (8) }\end{array}$ & $\begin{array}{l}\text { One patient was alive } 34 \text { months } \\
\text { after bilateral oophorectomy. }\end{array}$ \\
\hline $\begin{array}{l}\text { * Includes K } \\
\text { † Includes ei } \\
\text { † Six patient } \\
\S \text { Twelve pat }\end{array}$ & $\begin{array}{l}\text { sh and Soloway c } \\
\text { t cases from Woo } \\
\text { were } 35 \text { years old } \\
\text { nts were } 40 \text { years }\end{array}$ & $\begin{array}{l}\text { uff an } \\
\text { youn } \\
\text { dd or y }\end{array}$ & $\begin{array}{l}\text { Novak se } \\
\text { nger. }\end{array}$ & & & \\
\hline
\end{tabular}

was by Hale ${ }^{5}$ who studied the records of four major hospitals in Honolulu from 1945 through 1965. The patients ranged in age from 21 to 81 years; the average age was 45 years. Age distribution was made according to five-year groupings. Only two patients were included in the 20- to 25-year-old group; seven patients were in the 26 -to 30 -yearold group, and six patients were in the 31-to 35-yearold group, for a total of only 15 patients $(18.5 \%)$ aged 35 years or younger. There was a preponder- 

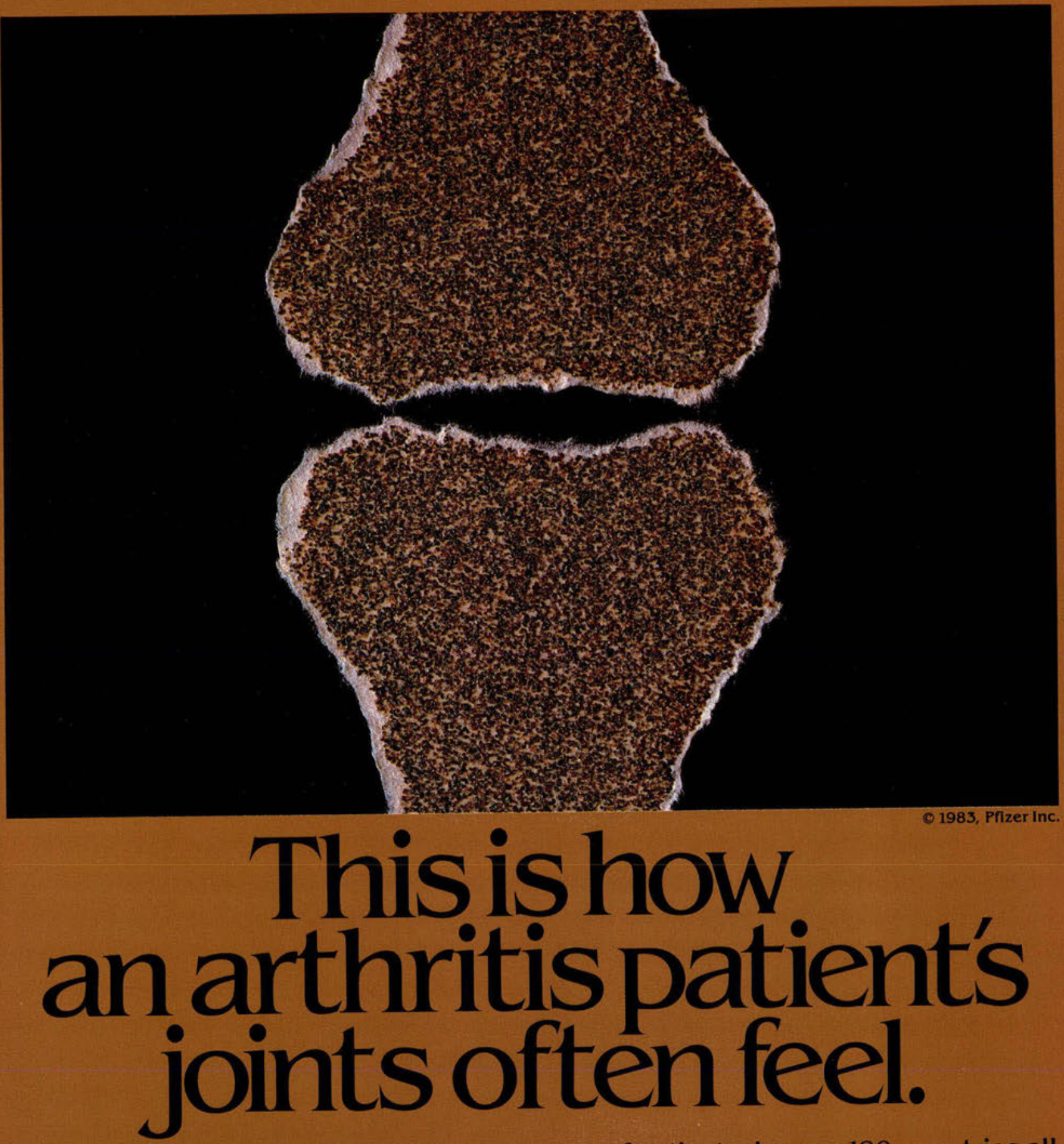

You can help these patients feel better with one-a-day FELDENE* (piroxicam). For good reasons:

- it's effective-proven relief of the pain and inflammation of rheumatoid arthritis and osteoarthritis' in millions

of patients, in over 100 countries all around the world.

- it's efficient-once daily, 20-mg dose provides round-the-clock relief, improves compliance and remains effective during long-term therapy.

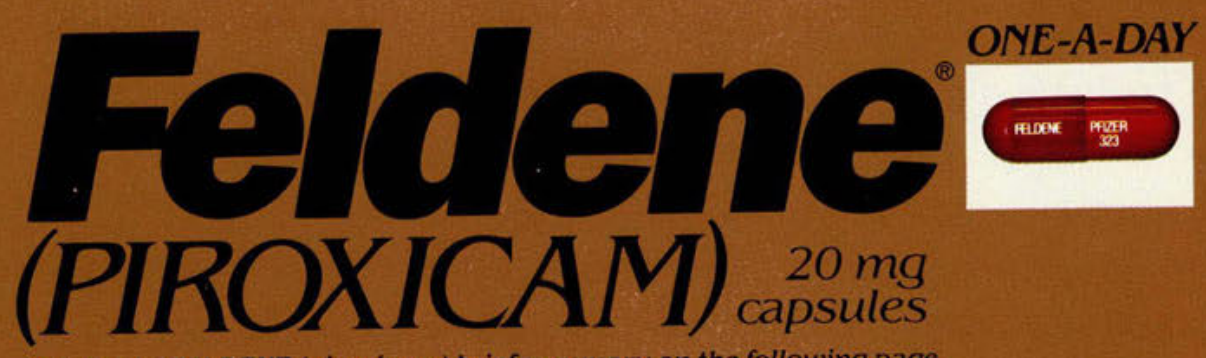

Please see FELDENE (piroxicam) brief summary on the following page. 


\section{Feldene (PIROXICAM) apong}

\section{Prescribe one $20 m g$ capsule dail for convenience anc compliance}
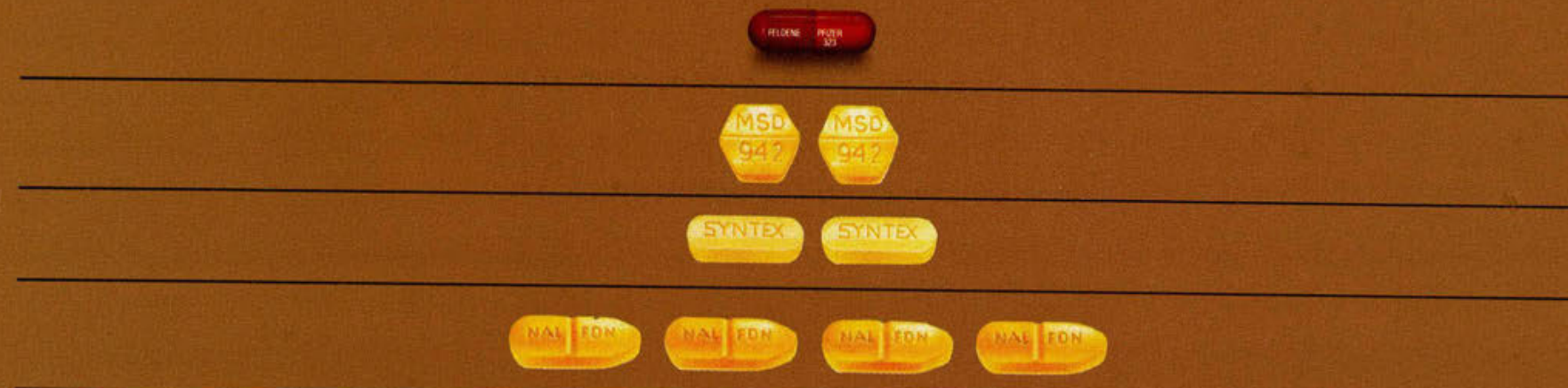

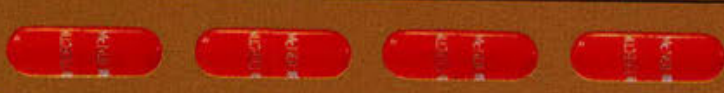

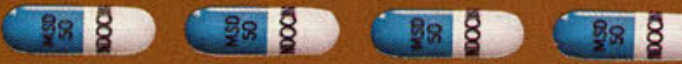 \\ 00000000000000000000}

Indicates maximum dosage for osteoarthritis and rheumatoid arthritis for the antiarthriticagents sho Source: PDR, 1989, Manufacturers' Prescribing Informatio

References: 1. Segmeth $W$ Serum concentrations of piroxicam in relation to its clinical effect in patients with chronic

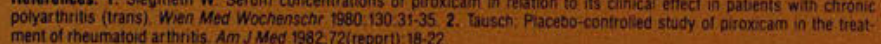

\section{Bnef Summary}

FELDEME $\cdot$ (piroxicam) Cagsales

CONTAAIMDICATIONS: FELDENE (piroxicam) should not be used in patients who have previously exhibited tiypersensitivity

to it, or in individuals with the syndrome comprised of bronchospasm, nasal polyps and angivederra precipitated oy aspirin or other nonsteroidal anti-inflammatory drugs

WARWIwGS: Peptic uiceration, pertoration, and G.I. bleedino-sometimes severe, and, in some instances fatal-have been reported with patients seceiving FELDENE. II FEL DENE must be given to patients with a history of upper gastrointes-
tinal tract disease, the patient should be under close sinerylsion (se AOVEPSE OEACT tinal tract disease, the patient should be under close supervision (see AOVERSE REACTIONS). Physicians should remain
alert for ulceration and bieeding in patients treated chronically with NSAIDs even in the absence of previous Gi tract symptoms

PAECAUTIOWS: Renal Eftects: As with other nonsteroidal ant-inflammatory drugs. long-term administration of piroxicam to animais has resulted in renal papillary necrosis and other abnormal renal pathology. In humans, there have been reports of acute interstitial nephritis with hematuria, proteinuria, snd occasionally, nephrotic syndrome.

A second form of renal toxicity has been seen in patients with prerenal conditions leading to a reduction in renal bloos Now or blood volume, where the renal prostaglandins have a supportive role in the maintenarice of renal perfusion in thes patients adrministration of an NSAID may cause a dose-dependent reduction in prostaglandin formation and may precipital overt renal decompensation. Patients at preatest risk of this reaction are those with impaired renal function, heart failure liver dystunction, those taking divetics, and the elderly

Because of extensive renal excretion of piroxicam and its biotranstormation products fless than $5 \%$ of the daily dosi excreted unchanped), lower doses of piroxicam should be anticipated in patients with impaired renal function, and they should be carefully monitorec

Aithough other nonsteroidal ant-intiammatory drugs do not have the same direct ettect on platelets that aspirin does all drugs inhibiting prostaglandin biosynthesis do interfere with plateiet function to soine degree

Because of reports of adverse eye findings with nonsteroidal anti-infismmatory agents, it is recommended that patients who deveiop visual compiaints ourng treatment with FEL.DENE have ophthalmic evaluatic

15\% with other nonsteroidal anti-intlammatory drugs, borderiline elevations of one or more liver tests may occur in up to 15\% of pavients. A patient with symptoms and/or signs suggesting liver dystunction, or in whom abnormal liver lests have FELDENE:

Severe hepatic reactions, including laundice and cases of tatal hepattis, have been reported with FELDENE. Although such reactions are rare, if abnormal liver tests persist or worsen, if clinical signs and symptomis consistent with iver dis ease develop, or if systemic manifestations occur $(0.9$. cosinophilia, rash, etc.), FELDENE shouid be discontinued. (Ser also ADVERSE REACTIONS.)

Although at the recommended dose of $20 \mathrm{mg} / d a y$ of FELLENE increased fecal blood loss due to gastrointestinal irritation did not occur, in about $4 \%$ of the patients treated with FELDENE alone or concomitantiy with aspirin. reductions in hem: globin and hematocrit values were observed.

Peripheral edema has been observed in approximately $2 \%$ of the patients treated with FELDENE. Therefore. FELDENF should be used with caution in patients with heart fallure, hypertension or other conditions gredisposing to fluid retention A combination of dermatological andior aliergic signs and symptoms sugpestive of serum sickness have occasionally occurred in conjunction with the use of FELDENE. These include arthralgias, pruritus, fever, fatigue, and rash including vesiculo bullous reactions and extoliative dermatitis

DRUG IWTERACrIOWS: Interactions with coumarin-type anticoagulants have been reported with FELDENE since marketing Therefore, physicians should closely monitor patients for a change in dosage requirements when administering FEL DENE to patients on coumarin-type anticoagutants and other highly protein-bound drugs

Plasma levels of piroxicam are depressed to approximately $80 \%$ of their normal values when FELDENE is auministered in conjunction with aspirin ( $3900 \mathrm{mg} /$ day), but concomitant administration of antacids has no eftect on piroxicam plasma level:

Nonsteroidal anti-inftammatory agents, Including FELOENE, have been reported to increase steady state plasma lithium ievels. It is recommended that plasma lithium lavels be monitored when initiating, adjusting and discontinuing FEL OENE: Carcinopenesis, Chronic Animal Toxicity and Impairment of Fertility: Subacute and chrenic toxicity studies have beer carried out in rats, mice, dogs, and monkeys

The pathology most often seen was that characteristically associated with the animal loxicology of anti-inflammatory
sgents: renal papillary necrosis (see PRECAUTIONS) and agents: renal papillary necrosis (see PRECAUTIONS) and pastrointestinal lesions

In classical studies in laboratory animals, piroxicam did not show any teratogenic potentia

Reproductive studies revealed no impairment of tertility in animals

Propnancy and Murning Molters: Like other drugs which inhibit the synthesis and release of prostaglandins, piroxicam trointestinal tract toxicity was increased in pregrant tempies in the loet tystocia and detayed parturition in animals. Ga: females or females in earlier trimesters of pregnancy
FEL DENE (piroxicam) is not recommended for use in nursing mothers or in pregnant women because of the animal finc ings and since saferty lor such use has not been established in humanis

Use in Children: Dosage recommendations and indications for use in children have not been established

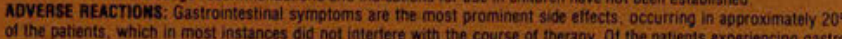
of the patients, which in most instances did not intertere with the course of therapy of the patienits experiencing sastr Adverse reactions are listed terien Adverse reactions are Incidence brester maans. The thequently than 1 in 100

diarthea abdominal pain indinestion Hematological decreases in tremeg

Dermatologic: pruritus, rash

Centrai Nervous System diziness, somnolence, vertigo

Urogenital BuN and creatinine elevations (see PRECAUTIONS

Body as a Whole headache, malaise

Special Senses: tinnitus

Gardiovascular/Respiratory : edema (see PRECAUTIONS) - Reactions occuring in $3 \%$ to $9 \%$ of patients treated with FELDENE. Reactions occurring in $1 \%$ to $3 \%$ of patients at
unnarked.

Incidence Less Than $1 \%$ (Causal Relationship Prooable) The lollowing adverse reactions occurred less trequently thar 1 in 100 . The probability exists that there is a causal relationstip between FEL OENE and these reactions

Gastrointestinal: liver function abnormalities, jaundice, hepatifis (see PRECAUTIONS), vomiting hematemesis. melen) gastrointestinal bleeding, perforation and viceration (see WARNINGS), dry mouth

Hemutological: thrombocytopenia, petechial rash, ecchymosis, bone martow depression including aplastic anemia epistaxis

Dermatologic sweating, erythema, bruising, desquamation, extoliative dermattis, erythema muitiorme. toxic epide mal necrolysis, Stevens Johnson syndrome, vesicuio bullous reactions, photoaliergic skin reactions

Centrai Nervous System: depression, insomnia, nervousnes:

Urogental hematuria, proteinuria, interstitial nephsitis, renal failure, hyperkalemis, glomerulitis, papillary necrosis lephrotic syndrome (see PRECAUTIONS)

sooy as a Whole pain (colic), tevec, fit-like syndrome (see PRECAUTIONS)

Special Senses: swolien eyes, blurred vision, eye inritations
Cardiovascular Resoiratory: hypertension, worsening of congestive heart talure (see PRECAUTiONS), exacerbation of

Metabolic: hypoglycemia, hyperglycemia, weight increase, weight decrease

Hypersensilivity anaphylaxis, bronchospasm, urticaria angioedema, vasculitis, 'serum sickness' (see PRECAUTIONS) Inciénce Leas Than $1 \%$ (Causal Relationship Unknown): Other adverse reactions were reported with a frequency of les Gastrointestinat: pancreatitis

Dermatologic onycholysis. loss of hair

Central Nervous System; akathisia, hallucinations, mood alterations. dream abnormalities, mental confusion paresthesias

Urogenital Systern dysuria
Body as a Whole weaknes

Gardiovascular:Respiratory palpitations, dyspnea

Hypersensitivity positive ANA

Special Senses: transient hearing loss

Hemutological: hernolytic anemil

OVERDOSAGE: in the event tieatment for overdosage is required, the long plasma halt ilte of piroxicarn should be consis ered. The absence of experience with acute overdosage procludes characterization of sequelae and recummendations of specinic antidotal efficacy at this time, It is reasonable to assume that the standard measures of gastric evacuation anc general supportive therapy would apply. In addition to supportive measures. the use of activated charcoai may effectively reduce the absorption and reabsorption of piroxicam. Experiments in dogs have demonstrated that the use of muitiple-dose ireatments with activated charcoas could reduce the hail-life of piroxicam efimination from 27 hours (without charcoals to 11 hours and reduce the systernic bioavailability of piroxicam by as much as $37 \%$ when activated charcoal is given as late as 6 hours after administration of piroxicam

DOMINISTRANON ANO DOSAGE: Rheumatoid Arthritis, Osteoarthritis: It is recommended that FELDENE therapy be ini iated and maintained at a single daily dose of $20 \mathrm{mg}$ If desired, the daly dose may be divided

Dosage recommendations and indications for use in children
More detalied professional information available on request

C1982. Pfizer inc. More detailed professional information available on requesi 
ance of Japanese patients in this series. The primary neoplasm site was the stomach in 76 patients $(94 \%)$. The colon and breast were the primary sites in three and two cases, respectively. Sixty-seven tumors $(83 \%)$ were bilateral. The largest ovary measured $22 \mathrm{~cm}$. The average duration from diagnosis until death was 7.1 months.

More recently, Holtz and $\mathrm{Hart}^{3}$ analyzed a series of 27 typical Krukenberg's tumors in patients ranging in age from 20 to 70 years. The exact age of each patient was not reported in the study. It is only known that the youngest patient was 20 years old. One case was described as involving "a young girl." Three patients had had recent pregnancies. Pleural effusions were present along with pulmonary metastasis in several patients, and osseous metastasis was found in eight patients.

Krukenberg's tumor accounts for only $3 \%$ to $5 \%$ of ovarian tumors. . $^{3,7,13}$ As in our case, symptoms typically are abdominal pain and distention secondary to pelvic masses and gastrointestinal distress. ${ }^{2,3,5,7,14}$ The duration of symptoms prior to diagnosis is variable, but it averages 2.6 months according to Hale. ${ }^{5}$ With the preoperative workup often helpful only in identifying ovarian masses, the exact diagnosis frequently is not made prior to surgery. ${ }^{3,5,7,13,14}$

At the time of diagnosis, the metastatic spread of tumor usually is extensive. Ascites, a prominent finding in our patient, has been reported in $46 \%$ to $64 \%$ of cases, and malignant pleural effusion has been found in about $8 \%$ of cases; both of these are regarded as poor prognostic signs..$^{5,7}$ In Hale's ${ }^{5}$ series, the average duration of disease from the onset of symptoms to death was 9.8 months. Prognosis depends partially on the advancement of disease prior to diagnosis and treatment. Surgery appears to offer the most benefit to patients with less advanced disease, and when the tumor appears to be limited to the organs removed. . $^{2,6,7,16}$

Although there is a dearth of information regarding Krukenberg's tumor in young patients, the typical characteristics do not appear to be altered by age. The peak age of Krukenberg's tumor patients (the fifth decade) is lower than that for gastric carcinoma (peak ages 55 to 65 ). ${ }^{1,12}$ Sixty percent of Krukenberg's tumor develop in patients who are still menstruating. ${ }^{13}$

Recent pregnancy and, occasionally, virilization are associated with the tumor. ${ }^{3,5,7,14}$ Because aggressive malignant metastatic disease frequently is seen in young persons, the patient's youth may obscure accurate diagnosis, because of the failure to suspect this secondary ovarian disease in the first three or four decades of life.$^{9,10}$ It is important, therefore, to report and describe cases in young patients with this unusual tumor.

\section{Summary}

Krukenberg's ovarian tumor rarely is seen by the community hospital surgeon, and its diagnosis in a young woman with bilateral ovarian masses often is not made until laparotomy. Such was the case with our 20-year-old patient, who at laparotomy was found unexpectedly to have Krukenberg's tumor with diffuse metastatic disease.

In the recent literature, few cases of this tumor in such a young patient can be found for comparison. To our knowledge, there has been no reported case of Krukenberg's tumor in a woman this young since 1982 , and this may be only the fifth documented case in such a young patient in the last 50 years.

Such cases should be reported so that more may be learned about the natural course and pathology of Krukenberg's tumor in young women and girls, and the tumor should be kept in mind as a differential diagnosis of bilateral ovarian masses.

1. Krukenberg FE: Uber das Fibrosarcoma Ovarii Mucocellulare (Carcinomatodes). Arch Gynakol 1866;50:287.

2. Scully RE: Tumors of the ovary and maldeveloped gonads, in Atlas of Tumor Pathology, series 2. Washington, DC, Armed Forces Institute of Pathology, 1982.

3. Holtz F, Hart WR: Krukenberg tumors of the ovary: A clinicopathologic analysis of 27 cases. Cancer 1982;50:2438-2447.

4. Ming S: Tumors of the esophagus and stomach, in Atlas of Tumor Pathology, series 2. Washington, DC, Armed Forces Institute of Pathology, 1982.

5. Hale RW: Krukenberg tumor of the ovaries: A review of 81 records. Obstet Gynecol 1968;32:221-225.

6. Metz SA, Karnei RF, Veach SR: Krukenberg carcinoma of the ovary with bone marrow involvement: Report of 2 cases and review of the literature. Obstet Gynecol 1980;55:99-104.

7. Woodruff JD, Novak ER: The Krukenberg tumor: Study of 48 cases from the Ovarian Tumor Registry. Obstet Gynecol 1960;15:351-360.

8. Joshi VV: Primary Krukenberg tumor of ovary: Review of literature and case report. Cancer 1968;22:1199-1207.

9. McNeer G: Cancer of the stomach in the young. AJR 1941;45:537540 .

10. Tamura PY, Curtiss C: Carcinoma of the stomach in the young adult. Cancer 1960;13:379-385.

11. Novak E, Gray LA: Krukenberg tumors of the ovary: Clinical and pathological study of 21 cases. Surg Gynecol Obstet 1938;66:157-165.

12. Karsh J: Secondary malignant disease of the ovaries: A study of 72 autopsies. Am J Obstet Gynecol 1951;61:154-160.

13. Soloway I, Latour JPA, Young MHV: Krukenberg tumors of the ovary. Obstet Gynecol 1956;8:636-638.

14. Bullon A Jr, Arseneau J, Prat J, et al: Tubular Krukenberg tumor: A problem in histopathologic diagnosis. Am J Surg Pathol 1981;5:225232.

15. Wong PC, Ferenczy A, Fan L-D, et al: Krukenberg tumors of the ovary: Ultrastructural, histochemical, and immunohistochemical studies of 15 cases. Cancer 1986;57:751-760.

16. Hornstein E, Skornick Y, Rozin R: Radical surgical treatment for Krukenberg tumor. Clin Oncol 1982;8:279-282.

17. Armstrong CP, Dent DM: Factors influencing prognosis in carcinomas of the stomach. Surg Gynecol Obstet 1986;162:343-348.

From the Department of Pathology and General Surgery, Olympia Fields Osteopathic Medical Center, Olympia Fields, Ill.

Reprint requests to Dr Gupta, Department of Pathology, Olympia Fields Osteopathic Center, 20201 S Crawford, Olympia Fields, IL 604611. 